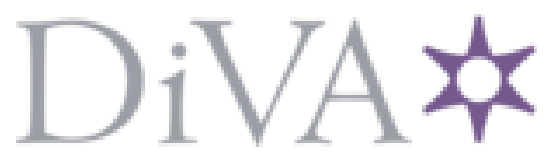

http://www.diva-portal.org

\title{
Postprint
}

This is the accepted version of a paper published in European Journal of Developmental Psychology. This paper has been peer-reviewed but does not include the final publisher proof-corrections or journal pagination.

Citation for the original published paper (version of record):

Dahl, V., Amnå, E., Banaji, S., Landberg, M., Šerek, J. et al. (2017)

Apathy or Alienation?: Political passivity among youths across eight European Union

Countries

European Journal of Developmental Psychology

https://doi.org/10.1080/17405629.2017.1404985

Access to the published version may require subscription.

N.B. When citing this work, cite the original published paper.

Permanent link to this version:

http://urn.kb.se/resolve?urn=urn:nbn:se:oru:diva-60647 
Apathy or Alienation? Political Passivity among Youths across Eight European Union Countries

\author{
Viktor Dahl $^{1}$ \\ Erik Amnå 1 \\ Shakuntala Banaji ${ }^{2}$ \\ Monique Landberg ${ }^{3}$ \\ Jan Šerek ${ }^{4}$ \\ Norberto Ribeiro ${ }^{5}$ \\ Mai Beilmann ${ }^{6}$ \\ Vassilis Pavlopoulos ${ }^{7}$ \\ Bruna Zani ${ }^{8}$
}

${ }^{1}$ Center for Studies on Civic Engagement, Department of Political Science, Örebro University,

Sweden

${ }^{2}$ London School of Economics and Political Science, UK

${ }^{3}$ Friedrich-Schiller-University, Jena, Germany

${ }^{4}$ Masaryk University, Brno, Czech Republic

${ }^{5}$ University of Porto, Portugal

${ }^{6}$ University of Tartu, Estonia

${ }^{7}$ National \& Kapodistrian University of Athens, Greece

${ }^{8}$ University of Bologna, Italy 
Correspondence concerning this manuscript should be addressed to: Viktor Dahl, Center

for Studies on Civic Engagement, Department of Political Science, Örebro University,

Fakultetsgatan 1, SE - 70182 Örebro, Sweden. E-mail: viktor.dahl@oru.se

Email addresses to co-authors

Erik Amnå: erik.amna@ oru.se

Shakuntala Banaji: s.banaji@1se.ac.uk

Monique Landberg: monique.landberg@uni-jena.de

Jan Šerek: serek@fss.muni.cz

Norberto Ribeiro: norberto@fpce.up.pt

Mai Beilmann: mai.beilmann@ut.ee

Vassilis Pavlopoulos: vpavlop@psych.uoa.gr

Bruna Zani: bruna.zani@ unibo.it

Keywords: political passivity, political apathy, political alienation, youths, European Union

This is an Accepted Manuscript of an article published by Taylor \& Francis in 'European Journal of Developmental Psychology' on 21 November 2017, available online: http:// www.tandfonline.com/10.1080/17405629.2017.1404985." 


\begin{abstract}
Political participation is one of the most studied aspects of the contemporary development of western democracies (Ekman \& Amnå, 2012; van Deth, 2014). A recent trend focuses the lack of political participation among younger generations (e.g., Henn, Weinstein \& Forrest, 2005; Kimberlee, 2002). At the same time, the last decades have also witnessed a growth in the share of young European Union (EU) citizens who express alienation, and distrust toward social and political institutions at the national as well as the European level (Dalton, 1998; Henn et al., 2005; Mierina, 2014). By studying young people across different countries of the EU, the current study aims to examine if youths' political passivity is better explained by political apathy or alienation. Our analyses are based on a comparative survey data collected by the Catch-EyoU project comprising approximately 4,454 late adolescents assembled from eight member countries of the EU. Results from logistic regressions predicting non-voting from apathy and alienation support the idea that political passivity is best understood as the result of political apathy. Moreover, it seems that the underlying separator of apathetic and alienated youths is cognitive awareness of political life. These results are discussed in relation to potentially built-in paradoxes of apathy present in efficient and well-functional welfare-state democracies.
\end{abstract}


Apathy or Alienation? Political Passivity among Youths across Eight European Union Countries

Political participation is one of the most studied aspects of the contemporary development of western democracies (Ekman \& Amnå, 2012; van Deth, 2014). A recent trend in research on this topic focuses the lack of political participation and its explanations among younger generations (e.g., Henn, Weinstein \& Forrest, 2005; Kimberlee, 2002). From this research it is notable that the last decades have witnessed a growth in the share of young European Union (EU) citizens who express alienation and distrust toward social and political institutions at the national as well as the European level (Henn et al., 2005; Mierina, 2014). Concerned with this development, Norris (2003, p. 2) argued that: "Political disengagement is thought to affect all citizens but young people are believed to be particularly disillusioned about the major institutions of representative democracy, leaving them either apathetic (at best) or alienated (at worst)."

Many studies on this topic label young people as either politically active or passive. However, such a dichotomy is likely a simplification as a seemingly passive stance can actually mask a latent political involvement (e.g., Amnå \& Ekman, 2014). This is important as it shows that, although it may be that Norris' depiction of young people is applicable in many places of the world, to assume that political passivity has the same meaning and consequence across contexts is likely a misguided presumption (Fox, 2015). In light of these puzzles concerning political passivity, this study aims to deepen the knowledge about political passivity by examining whether it is explained better by political apathy or alienation. 
Previous research on political apathy and alienation

\section{Political apathy and alienation}

Some 60 years ago, Dean (1960, p. 187) claimed that political apathy usually is "defined simply as voting or nonvoting," referring, naturally, to the inactive deed in this dichotomy. In similar vein, understanding political apathy as a lack of involvement in political participation is common also in contemporary research (O’Toole, Lister, Marsh, Jones \& McDonagh, 2003; Cammaerts, Bruter, Banaji, Harrison \& Anstead, 2014). In contrast to such definitions however, we follow the logic of Fox (2015) and define political apathy as lack of a desire, or motive, to take an interest in politics. This means that apathy is understood exclusively as an attitudinal orientation not to be confounded with a lack of political participation. This approach to political apathy opens for the possibility to examine also behavioral consequences of an indifferent stance toward politics. Stated differently, with this approach we can examine the extent to which political apathy explains young people's political passivity.

In general, the average level of political apathy seems to be very stable (Prior, 2010). Using several databases of general populations to examine the development of political interest, Prior showed that in general, the aggregate level of political interest does not change very much over time, irrespective of context. With regard to young people, however, research shows a different picture. Political apathy seems more widespread among younger generations and youths' political apathy is more pronounced nowadays compared to previously (Bennett, 2000; Henn et al., 2005).

Turning to political alienation, Lane (1962, p. 161) stated that it refers to "a person's sense of estrangement from the politics and government of his[/her] society." A common way to conceptualize political alienation is to extract it into four dimensions: powerlessness, 
normlessness, meaninglessness, and isolation (Finifter, 1970). Because the latter two seem to be empirical unrealities (Finifter, 1970; Fox, 2015), and thereby foremost of theoretical value, this study focuses on powerlessness and normlessness. Political powerlessness reflects "an individual's feeling that $[\mathrm{s}] /$ he cannot affect the actions of the government... [and that] the heart of the political process... is not subject to his[/her] influence" (Finifter, 1970, p. 390). Political normlessness, in turn, refers to "the individual's perception that the norms and rules intended to govern political relations have broken down, and that departures from prescribed behavior are common" (Finifter, 1970, p. 390).

Much research has addressed the political alienation of young people. Amongst other things, some scholars have claimed that political alienation may be superior to political apathy in explaining young peoples' non-voting (Henn et al., 2005). Additionally, when it comes to the underpinnings of political alienation, Gniewosz, Noack and Buhl (2009) showed that both parents and school ought to have important roles for the development of political alienation among young people. Their study assessed the powerlessness dimension of political alienation and found that parents' political alienation as well as more transparent teaching techniques could explain variations in young peoples' evaluations of citizens' influence on public affairs.

There seems to be both similarities and differences between political apathy and alienation. Conceptually, Fox (2015) argues that both political apathy and alienation are relatively stable political orientations, best understood as continuums. But these similarities must not lead to a mix-up of the two concepts, as unfortunately sometimes have been the case (e.g., Farthing, 2010). Their similarities aside, the extent to which apathy and alienation are related is contested. For instance, Neuman (1957, p. 290) posits that political alienation is a "conscious rejection of the whole political system which expresses itself in apathy." In similar 
vein, early investigations of the concepts found political alienation to be positively related to political apathy (Dean, 1960). However, the low magnitude of their correlation led the author to conclude that the two should be understood as distinct concepts. A crucial aspect that differs between the two is that alienation is an active orientation with a strong sense of cognitive awareness (Fox, 2015). That is, compared with apathetic, alienated individuals are more aware of what it is that they are alienated from. By comparison, the cognitive awareness of apathetic individuals is very low and apathetic individuals know only enough about politics to tell that politics is not in their interest.

\section{Predicting political passivity}

The cognitive-awareness differences of political apathy and alienation suggest that the two also have different behavioral consequences. Behavioral consequences for apathy are "less the direct consequences of an active orientation than the reflection of a lack of motivation to do anything else $[\ldots]$ : higher levels of apathy imply lower levels of motivation [...], which in turn implies lower levels of political participation" (Fox, 2015, p. 153). The likelihood to vote for individuals expressing high levels of political apathy is therefore low. With regard to behavioral consequences of alienation, scholars anticipate that politically alienated individuals might act in one of the following two ways: 1) exit the scene, and 2) take remedial action (Hirschman, 1970). Hence, alienation may result in individuals exiting the scene by refusing to vote, or, choosing to voice discontent by using for instance unconventional political means. In sum, the overarching question of this study addresses whether young people's abstention from voting is foremost due to apathy or alienation. Consequently, we asked the following research question: 
Is political apathy or alienation better at explaining political passivity among youths in the European Union?

\section{Method}

\section{Participants and procedure.}

For this study, we use the first wave of the comparative survey of youths collected in 2017 in eight EU countries by the Catch-EyoU project $^{1}$. The data comprise survey answers from 4454 youths collected in Czech Republic $(n=528)$, Estonia $(n=571)$, Germany $(n=647)$, Greece $(n$ $=476)$, Italy $(n=814)$, Portugal $(n=465)$, Sweden $(n=400)$, and the United Kingdom $(n=$ 553). The selected countries thereby target new and old EU member states, countries with different welfare regimes, Nordic, central European, and Southern European countries. Beyond this diversity, participants were strategically chosen to represent societal diversity throughout the EU. The data collections therefore aimed to target both boys and girls with varying social and ethnic backgrounds. Most countries collected their data in school. The extent to which the collected data equate with national averages on relevant factors varied greatly across countries. In general, females are overrepresented in the sample. For this study, the analytic sample comprised young people within the 14-20 age-range, enrolled in both vocational and academic programs $\left(N=4454 ; 56.2 \%\right.$ girls; $\left.M_{\text {age }}=16.56 ; S D=1.09\right)$.

The data were collected using both paper (67\%) and online (33\%) questionnaires. Participants were informed about the types of questions included in the questionnaire, the amount of time to finish, and that their participation was voluntary. Participants were also guaranteed that their answers would not be seen by parents, teachers, or anyone else. When collected in school, teachers were not present. 


\section{Measures}

Political apathy. We used three questions asking about youths' political interest to assess their political apathy: "How interested are you in politics?" "How interested are you in what is going on in society?", and "How interested are you in European Union related topics?" From these questions we created a scale of youths' political apathy (Cronbach's $\alpha_{\text {range }}=0.78-0.86$ ). The response scale for all three questions was inverted so as to measure apathy: 1 "Extremely interested" to 5 "Not interested at all."

Political alienation. We measured two dimensions of political alienation. Powerlessness was measured with the stem question: "How much do you agree or disagree with the following?" We assessed powerlessness with four statements: "People like me do not have opportunities to influence the decisions of the European Union," "It does not matter who wins the European elections, the interests of ordinary people do not matter," "People like me do not have opportunities to influence the decisions of the national parliament," and "It does not matter who wins the [country's] elections, the interests of ordinary people do not matter." Respondents could answer from 1 "Strongly disagree" to 5 "Strongly agree." These items were averaged into a powerlessness index (Cronbach's $\alpha_{\text {range }}=0.69-0.87$ ).

Due to its close relation to political trust, and in concordance with prior research (e.g., Fox, 2015), this study used items measuring institutional trust as a proxy of normlessness. We asked the respondents: "Please indicate how much you agree or disagree with the following statements." We thereafter provided two statements to capture their perception of normlessness: "I trust the European Union" and "I trust the national government." The response scale ranged from 1 "Strongly disagree" to 5 "Strongly agree." The statements were inverted and thereafter 
averaged to create a normlessness scale (Pearson's $\left.r_{\text {range }}=0.35-0.79\right)$. For details on inter-item reliability, see Appendix 1, Table 6.

Non-voting. We asked respondents to indicate whether or not they intend to vote in future: a) general elections, and b) the European parliament elections: "One of the ways in which people can express their opinion is by voting. Please indicate below the option that best describes you. Will you vote in the next national parliamentary elections/next European parliament elections?" There were three answers to choose among: 1 "Yes," 2 “No," and 3 "I don't know yet." Because we are foremost interested in why respondents abstain from voting, both variables were recoded so that the yes and the don't-know option had the score 0 and the negative option the score 1 .

Unconventional political participation. This measure is an average of responses to three statements about involvement in unconventional political participation during the last 12 months. The stem question read: "People can express their opinions regarding important local, environmental or political issues. We do so by participating in different activities. Have you done any of the following in the past 12 months?" The statements are: "Painted or stuck political messages or graffiti on walls," "Taken part in an occupation of a building or a public space," and "Taken part in a political event where there was a physical confrontation with political opponents or with the police" (Cronbach's $\left.\alpha_{\text {range }}=0.55-0.94\right)$. Respondents could answer 1 "No," 2 "Rarely," 3 "Sometimes," 4 "Often," or 5 "Very often.” We recoded this measure so that involvement had the score 1 and non-involvement 0 . 


\section{Strategy of Analysis}

We expect that young people's non-voting, that is, their political passivity, will be connected to social, economic, and political characteristics of the eight EU countries under study. We therefore explored the political passivity of young people in the EU foremost through countrybased analyses. First, we wanted to get a better understanding of our two explanatory factors. Hence, we started by examining levels of political apathy and alienation across the eight countries. We examined potential country differences using analyses of covariance (ANCOVAs) and independent samples $t$-tests. Finally we used logistic regression analyses and complementary chi-square tests to examine the extent to which apathy and alienation explains youths' political passivity and unconventional political participation. All our primary analyses were controlled for gender, immigrant status, and income.

\section{Results}

\section{Political passivity across different contexts}

Table 1 shows the shares of young people in each country that report inclinations for a non-vote in upcoming national and EU elections. As can be seen from these results, youths in most of the eight countries harbor the same inclinations for a non-vote irrespective of if considering the national or the EU election. The exception is Greece, and to some extent the UK, where the share reporting that they will not vote in upcoming EU elections far exceeds the share reporting that they will abstain an upcoming vote in future national elections.

\section{Political apathy and alienation across different contexts}

The mean comparisons of Table 2 show that political apathy and alienation differs between the eight countries in the sample. With regard to political apathy, mean comparisons across the 
countries show that political apathy reaches its peaks in Czech Republic and Italy, and its low in the UK. However, most countries in the study differ very little with regard to their level of political apathy. Only the UK stands out with significantly lower levels of political apathy compared to all other countries under study.

With regard to political alienation, mean comparisons across the countries show that powerlessness reaches its peaks in Czech Republic and Greece, and its low in Sweden. We find also the lowest levels of normlessness in Sweden. Additionally, young people in Greece exceeds youths in all the other countries and come out as the single most alienated youth group with regard to normlessness. It is not easy to reach a clear conclusion with regard to comparisons of powerlessness and normlessness within the eight countries. In all but one country (Czech Republic), powerlessness and normlessness appears to reach different levels. However, four of the countries show significantly higher levels of powerlessness (Estonia, Germany, Portugal, and the UK) and three of the countries (Greece, Italy, and Sweden) show significantly higher levels of normlessness.

Finally, using Pearson's $r$, we also examined the extent to which the different forms of political apathy and alienation are associated. The results show that political apathy and alienation generally are related, although foremost to a weak extent (apathy - powerlessness: modal correlation $=.12 * * *[$ lowest $=.02$; highest $=.20 * * *]$; apathy - normlessness: modal correlation $=.22 * * *[$ lowest $=.10 *$, highest $=.31 * * *])$.

\section{Explaining political passivity with political apathy and alienation}

We explored young people's inclinations for non-voting in forthcoming general elections and European parliament elections. For both these outcomes, we tested four separate models by country: 1) a model including only controls, 2) an apathy model, 3) an alienation model, and 4) a 
model including both apathy and alienation. We made use of a Wald test to compare the apathy and the alienation models with the control model respectively and then in the combined model, we compared the effect of apathy with the effects of alienation. Table 3 shows a summary of these results. Each column in the table specifies the model, for a specific country, that was best at explaining a certain outcome. In Czech Republic, for instance, Unconventional political participation (U) was best explained by the Control model, non-voting in the national election (N) was best explained by the Apathy model, and non-voting in the European parliament election (E) was best explained by the Combined model (see Appendix 1 for full model information).

Concerning political passivity in general elections, the results show that the apathy model was the best at predicting non-voting in general elections in Czech Republic and Germany and that the combined model was the best in Estonia, Greece, and Italy. Moreover, political alienation was never a sole explanatory factor of intentions not to vote in forthcoming general elections. Stated differently, in the five countries where political apathy and alienation explained young people's intentions for non-voting in forthcoming general elections, political apathy was predicting non-voting equally well as, or better than, alienation.

The analyses of young people's inclinations for non-voting in European parliament elections showed similar results. That is, both political apathy and alienation explained nonvoting in the EU election. In Portugal and the UK, positive effects from apathy and alienation were present but the effects were not significant, nor were they different in strength while controlled for each other in the combined model. Moreover, the roles of apathy and alienation was not decisive in Greece; the non-significant Wald test of Model 4 suggest that effects from both apathy and normlessness were present. However, the AIC and BIC indices suggest that the apathy model is best at explaining young Greeks' non-voting in future EU elections. In the 
remaining five countries, a non-vote in future EU elections was best explained by apathy and alienation, most often in the form of powerlessness. For these countries, the normlessness dimension of alienation had no significant impact on inclinations for non-voting in the EU election. In sum, irrespective of if focusing general or EU elections, there seems to exist country variations in the extent to which political apathy and alienation predicts non-voting. Notably, though, in instances where the two factors do predict inclinations of a non-vote, political apathy seems always to be present.

From these analyses it seems that, compared with political alienation, apathy has a superior role in explaining political passivity. However, theory states that next to exiting, alienation may result in remedial action as well. Perhaps alienation takes its expression not as exiting (political passivity) but foremost as remedial action? To answer this question, we compared the effects of apathy and alienation on unconventional political participation in models equivalent to those for non-voting. In Czech Republic, Estonia, and Greece, the control model was the best at predicting unconventional political participation, indicating that political apathy and alienation have very limited roles in predicting unconventional political participation at all in some countries. The control model was also best for Italy but a closer look at Table $5 \mathrm{c}$ reveals a positive, significant effect of normlessness for unconventional political participation. In Germany, Sweden, and the UK, unconventional political participation was positively predicted by some form of alienation. Only in Portugal was unconventional political participation predicted positively by apathy. Hence, the analyses suggest that for unconventional political participation, alienation has a stronger role to play compared with apathy.

So far, the analyses have enlightened us with several findings that can illuminate the political passivity of young European citizens. Nevertheless, when exploring non-votes in the 
data we also wanted to examine more in depth the reasons underlying young people's nonvoting. Among youths expressing that they would not vote in upcoming elections (general or European parliament elections), respondents were asked also to report about the reasons for casting a non-vote. To take advantage of these data, we selected only non-voters for a final analysis. Given that this selection of only non-voters reduced the sample size considerably, we decided to conduct this part of the analysis on the whole sample. We thereafter compared nonvoters expressing high levels of political apathy with non-voters expressing high levels of alienation (powerlessness) on: a) an indifferent attitude to elections, and b) a lack of valid options to vote for. The results showed that whereas apathetic youths showed to be more than twice as likely as alienated youths to answer "I don't care" ( $p<0.001)$ as their reason not to vote, alienation youths were more than four times as likely to motivate their choice to abstain with the reason that "I don't think any candidates will represent my views" ( $p<0.001)$ (Table 4). These differences appeared irrespective of if the respondent was addressing an upcoming general or European parliament election.

\section{Discussion}

This study set out to examine if youths' political passivity is better explained by political apathy or alienation. Our analyses point toward an answer suggesting that in terms of non-voting, political passivity is best explained by political apathy. Nevertheless, certain more nuanced patterns appeared from comparing across the contexts as well.

First, irrespective of its underlying reason, this study suggests that political passivity measured as future non-voting intentions - is present among youths in today's EU. Second, whereas political apathy seems better at explaining political passivity than alienation, alienation 
appeared to be the strongest factor of the two when it came to unconventional political participation. As earlier studies suggest a similar outcome (e.g., Southwell \& Everest, 1998), to find alienation more closely related to unconventional political participation was not a surprise. However, that political apathy seems better than alienation at explaining young people's political passivity goes counter to what has been suggested previously (Henn et al., 2005). Noted should be that the presence of political apathy and alienation both challenges the overall participatory democratic ideal of an active citizenship. This ideal is widely cherished and supported by the EU and their youth policies in particular (Amnå \& Ivarsson, 2017). However, while the apathetic stance of passivity needs to be recognized and better understood, the alienated orientation calls for an even wider concern by national as well as European political institutions.

From the results of this study it seems that reasons underlying a non-vote corresponds effectively with a rational. It is clear that non-voters' cognitive awareness about politics is a divider that distinguishes an apathetic non-vote from an alienated one: Some young people do not care enough about politics to partake through its representative channels, other youths abstain the vote because they possess the competence to evaluate the extent to which the act of voting is of any use to them. And, as it seems, alienated youths take to other means in order to influence public affairs. So, what we observe in this and other studies on political passivity is possibly a vicious circle. Compared with older generations', young people's interests are likely not represented to the same extent in the democratic decision-making process. And this, in turn, suggests that young people have the propensity to feel even more apathetic toward and alienated from public affairs. As more apathy and alienation seem linked to non-voting, the likelihood to remedy a non-representative assembly through means of increased participation is far away. Additionally, the electoral success of populist parties across European politics can be seen as a 
failure of the established parties' attempts to convince youths that political leaders listen and care about people like them. What might be able to turn this unwelcomed situation is that other political parties strengthen their position among youths. For one thing, political parties must try harder to find young people willing to run for political offices. Such increasing attempts from the parties' side might assure younger voters that their experiences and life-situations are taken into consideration when policies are developed. In other words, there is a need to deepen: "[T]he feeling that individual political action does have, or can have, an impact upon the political process, i.e. that it is worthwhile to perform one's civic duties. It is the feeling that political and social change is possible, and that the individual citizen can play a part in bringing about this change" (Campbell et al., 1954, p. 187).

A couple of limitations of the current study should also be mentioned. First, our outcome measure of political passivity was intentions (not) to vote. Hence, to the extent that this study can further the knowledge on young people's political passivity, such wisdom is based on respondents' anticipations of their future intentions regarding voting in national and EU referendum. Naturally, such expectations carry with them a certain level of uncertainty and should thereby be interpreted with caution. Second, the country-level data collections carried out for this project were primarily conducted in schools in a none-representative manner. The extent to which the data equate with national averages on relevant factors therefore differs considerably between countries. Hence, readers should be careful when generalizing these data to other contexts and preferably, the findings of this study need to be replicated in representative samples in order to further their relevance.

This study concludes that political passivity is very much a present political orientation of European youths. Passivity is not only present both as political apathy and alienation, it also 
seem to have consequences for how young people express their political interest and behavior. What future studies on this topic should focus on, though, which was missing in this analysis, is to disentangle the extent to which politically apathetic individuals ignore politics because they are content with how society is functioning and with how the political system reaches, according to them, favorable outcomes (Amnå \& Ekman, 2015; Rosenberg, 1954). Such an analysis should also be complemented with a more comprehensive understanding of how young people conceptualize politics. Presently, research on young people's understanding of politics is lacking. But we know from studies on adults that the conceptual breath of 'what is political' varies considerably and that different connotations also have different behavioral consequences (Fitzgerald, 2013). Hence, the meaning of young people's political passivity and its consequences is still very much in need of further inquiry. 


\section{References}

Amnå, E. \& Ivarsson, J. (2017). Perspectives of policy makers on EU and on youth active citizenship. Catch- EyoU Blue Paper, available at http://www.catcheyou.eu/theproject/publications/wp3bp/

Amnå, E. \& Ekman, J. (2014). Standby citizens: diverse faces of political passivity. European Political Science Review, 6(2), 261-281.

Amnå, E. \& Ekman, J. (2015). Standby Citizens: Understanding Non-Participation in Contemporary Democracies, in Barrett, M. \& Zani, B (Eds.) Political and Civic Engagement: Multidisciplinary Perspectives (pp. 96-108). Abingdon: Routledge.

Bennett, S. E. (2000). Political apathy and avoidance of news media among generations X and Y: America's continuing problem. Education for civic engagement in democracy: Service learning and other promising practices, 9-28.

Cammaerts, B., Bruter, M., Banaji, S., Harrison, S., \& Anstead, N. (2014). The myth of youth apathy: Young Europeans' critical attitudes toward democratic life. American Behavioral Scientist, 58(5), 645-664.

Campbell, A., Gurin, G., Miller, W. (1954). The Voter Decides. Evanston, IL: Row, Peterson.

Dean, D. G. (1960). Alienation and political apathy. Social Forces, 38(3), 185-189.

Ekman, J. \& Amnå, E. (2012). Political participation and civic engagement: towards a new typology. Human Affairs, 22(3), 283-300.

Farthing, R. (2010). The politics of youthful antipolitics: representing the 'issue' of youth participation in politics. Journal of youth studies, 13(2), 181-195.

Finifter, A.W. (1970). Dimensions of Political Alienation, The American Political Science Review, 64(2), 389-410. 
Fitzgerald, J. (2013). What does "Political” Mean to You? Political Behavior, 35(?), 453-479.

Fox, S. (2015) Apathy, alienation and young people: The political engagement of British Millennials, available at http://eprints.nottingham.ac.uk/30532/1/Final\%20Corrected\%20Version\%20\%20Apathy,\%20Alienation\%20and\%20Young\%20People\%20The\%20Political\%20Enga gement\%20of\%20British\%20Millennials.pdf [Accessed 10th February 2017]

Gniewosz, B., Noack, P., \& Buhl, M. (2009). Political alienation in adolescence: Associations with parental role models, parenting styles, and classroom climate. International Journal of Behavioral Development, 33(4), 337-346.

Henn, M., Weinstein, M., \& Forrest, S. (2005). Uninterested youth? Young people's attitudes towards party politics in Britain. Political studies, 53(3), 556-578.

Hirschman, A. O. (1970). Exit, voice, and loyalty: Responses to decline in firms, organizations, and states. Harvard university press.

Kimberlee, R. H. (2002). Why don't British young people vote at general elections?. Journal of youth studies, 5(1), 85-98.

Lane, R. E. (1962). Political ideology: why the American common man believes what he does. New York: Free Press.

Mierina, I. (2014). Political Alienation and Government-Society Relations in Post-Communist Countries, Polish sociological review, ?(?), 3-24.

Norris, P. (2003). Young people \& political activism: From the politics of loyalties to the politics of choice? Paper presented to the Council of Europe Symposium, Young People and Democratic Institutions: From Disillusionment to Participation, Strasbourg, 27th - 28th November 2003. 
O'Toole, T., Lister, M., Marsh, D., Jones, S., \& McDonagh, A. (2003). Tuning out or left out? Participation and non-participation among young people. Contemporary politics, 9(1), 45-61.

Prior, M. (2010). You've either got it or you don't? The stability of political interest over the life cycle. The Journal of Politics, 72(3), 747-766.

Rosenberg, M. (1954). Some determinants of Political Apathy, The Public Opinion Quarterly, 18(4), 349-366.

Southwell, L. L., \& Everest, M. J. (1998). The Electoral Consequences of Alienation: Nonvoting and Protest Voting in the 1992 Presidential Race, The Social Science Journal, 35(1), 4351.

Van Deth, J. W. (2014). A conceptual map of political participation. Acta Politica, 49(3), 349367. 
${ }^{1}$ CATCH-EyoU has received funding from the European Union's Horizon 2020 research and innovation programme under Grant Agreement N. 649538 
Table 1.

Inclinations for non-voting in upcoming national and EU elections. Percentages.

\begin{tabular}{lcccccccc}
\hline & Czech & Estonia & Germany & Greece & Italy & Portugal Sweden & UK \\
& Republic & & & & & & & \\
& & & & & & & & \\
\hline Non-voting in national elections & 35.0 & 32.6 & 46.2 & 40.2 & 37.2 & 45.3 & 18.7 & 12.4 \\
Non-voting in EU elections & 31.2 & 35.9 & 43.5 & 58.9 & 38.2 & 47.6 & 18.2 & 19.3 \\
\hline
\end{tabular}


Table 2.

Analysis of covariance (ANCOVA) of political passivity $\times$ country, controlling for gender, country of birth, and income.

$\begin{array}{lllllllll}\text { Czech Estonia } & \text { Germany } & \text { Greece } & \text { Italy } & \text { Portugal } & \text { Sweden } & \text { UK } & F \text {-values (d.f.) } & \eta^{2}\end{array}$

Republic

\begin{tabular}{|c|c|c|c|c|c|c|c|c|c|c|}
\hline Apathy & $3.33^{\mathrm{abc}}$ & $3.18^{\text {bcde }}$ & $3.01^{\mathrm{def}}$ & $2.97^{\mathrm{ef}}$ & $3.29^{\mathrm{abcd}}$ & $3.06^{\text {cdef }}$ & $3.21^{\text {abcde }}$ & $2.17^{\mathrm{g}}$ & $88.42_{(7,4120)}$ *** & 0.13 \\
\hline \multicolumn{11}{|l|}{ Alienation } \\
\hline Powerlessness & $3.45^{\mathrm{a}}$ & $3.37^{\mathrm{ab}}$ & $3.21^{\mathrm{bc}}$ & $3.43^{\mathrm{a}}$ & $3.21^{\mathrm{bc}}$ & $3.09^{\mathrm{c}}$ & $2.74^{\mathrm{d}}$ & $3.18^{\mathrm{bc}}$ & $23.09_{(7,4215)} * * *$ & 0.04 \\
\hline Normlessness & $3.46^{\mathrm{b}}$ & $3.02^{\mathrm{c}}$ & $3.00^{\mathrm{c}}$ & $3.78^{\mathrm{a}}$ & $3.52^{b}$ & $2.99^{c}$ & $2.84^{\mathrm{c}}$ & $2.96^{\mathrm{c}}$ & $86.49_{(7,4113)} * * *$ & 0.13 \\
\hline Mean difference test & -0.01 & $0.35^{* * *}$ & $0.21 * * *$ & $-0.35 * * *$ & $-0.32 * * *$ & $0.12 *$ & $-0.13^{* *}$ & $0.21 * * *$ & & \\
\hline
\end{tabular}

Note: ${ }^{*} p<.05 ; * * p<.01 ; * * * p<.001$ 
Table 3.

Summary of best models for predicting inclinations for non-voting in forthcoming elections and unconventional political participation.

\begin{tabular}{|c|c|c|c|c|c|c|c|c|}
\hline & Czech & & & & & & & \\
\hline Model & Republic & Estonia & Germany & Greece & Italy & Portugal & Sweden & UK \\
\hline 1. Control & $\mathrm{U}$ & $\mathrm{U}$ & & $\bar{U}$ & $\mathrm{U}$ & $\mathrm{NE}$ & $\mathrm{N}$ & $\mathrm{NE}$ \\
\hline 2. Apathy & $\mathrm{N}$ & & $\mathrm{N}$ & $\mathrm{E}$ & & & & \\
\hline 3. Alienation & & & & & & & & $\mathrm{U}$ \\
\hline 4. Combined & $\mathrm{E}$ & $\mathrm{NE}$ & EU & $\mathrm{N}$ & $\mathrm{NE}$ & $\mathrm{U}$ & EU & \\
\hline
\end{tabular}

Note: $\mathrm{N}=$ National election; $\mathrm{E}$ = European parliament election; $\mathrm{U}=$ Unconventional political participation. 
Table 4.

Reasons for non-voting in upcoming elections. Percentages.

\begin{tabular}{|c|c|c|c|c|c|}
\hline & & & Apathetic & Alienated & $C h i^{2}(p$-value $)$ \\
\hline \multirow[t]{4}{*}{ I don't care } & $n=537$ & General elections & 31.7 & 12.5 & 29.65 \\
\hline & & & & & $(<0.001)$ \\
\hline & $n=698$ & European parliament elections & 22.7 & 11.9 & 11.33 \\
\hline & & & & & $(<0.001)$ \\
\hline \multirow[t]{4}{*}{ I don't think any candidates will } & $n=537$ & General elections & 3.4 & 13.7 & 15.50 \\
\hline & & & & & $(<0.001)$ \\
\hline & $n=698$ & European parliament elections & 4.2 & 11.9 & 14.46 \\
\hline & & & & & $(<0.001)$ \\
\hline
\end{tabular}

